\title{
Peripartal feeding strategy with different $n-6: n-3$ ratios in sows: effect on gene expression in backfat white adipose tissue postpartum
}

\author{
Georgios A. Papadopoulos ${ }^{1,2 *}$, Tim Erkens ${ }^{3}$, Dominiek G. D. Maes ${ }^{2}$, Luc J. Peelman ${ }^{3}$,
}

Theo A. T. G. van Kempen ${ }^{4}$, Johan Buyse ${ }^{5}$ and Geert P. J. Janssens ${ }^{1}$

${ }^{1}$ Laboratory of Animal Nutrition, Faculty of Veterinary Medicine, Ghent University, Heidestraat 19, B-9820 Merelbeke, Belgium

${ }^{2}$ Department of Reproduction, Obstetrics and Herd Health, Faculty of Veterinary Medicine, Ghent University, Salisburylaan 133, B-9820 Merelbeke, Belgium

${ }^{3}$ Laboratory of Genetics, Faculty of Veterinary Medicine, Ghent University, Heidestraat 19, B-9820 Merelbeke, Belgium

${ }^{4}$ Provimi Research and Inovation Centre, Lenneke Marelaan 2, B-1932 Sint-Stevens-Woluwe, Belgium

${ }^{5}$ Department of Biosystems, Laboratory of Physiology, Immunology and Genetics of Domestic Animals, Catholic University of

Leuven, Kasteelpark Arenberg 30, B-3001 Heverlee, Belgium

(Received 17 February 2008 - Revised 7 April 2008 - Accepted 18 April 2008 - First published online 23 May 2008)

\begin{abstract}
The aim of this study was to describe the effects of two diets differing in $n-6: n-3$ ratio and prepartal feeding regime on gene expression of PPAR $\gamma 1 \mathrm{a} / 1 \mathrm{~b}$, PPAR $\gamma 1 \mathrm{c} / 1 \mathrm{~d}$, PPAR $\gamma 2$, PPAR $\gamma$ coactivator 1A (PPARGC1A), GLUT4, TNF $\alpha$, adiponectin, leptin, leptin receptor (LEPR), fatty acid binding protein 4 (FABP4), lipoprotein lipase (LPL) in sows' white adipose tissue on the first day of lactation. The relationship between mRNA expression of these genes and circulating insulin, leptin and thyroid hormones was also considered. Diets contained a low (supplemented with fish oil; f group) or a high (supplemented with sunflower oil; s group) $n-6: n-3$ ratio and were provided from 8 (f8, s8) or $3 \mathrm{~d}$ (f3, s3) before parturition (onset day 8 or 3). A low $n-6: n-3$ ratio reduced the $1 \mathrm{~d}$ postpartum expression of PPAR $\gamma 2$ and PPARGC1A but only when applied from $3 \mathrm{~d}$ before parturition. Circulating leptin was negatively correlated with mRNA expression of adiponectin, LEPR and LPL, whereas thyroxine was positively correlated with levels of PPARGC1A. In conclusion, the effect of dietary treatments, e.g. altering the $n-6: n-3$ ratio, around parturition on the expression of crucial genes in nutrient metabolism can be modulated by the duration of application before parturition.
\end{abstract}

Lactating sow: $n-6: n-3$ ratio: PPAR $\gamma$ : PPARGC1A: White adipose tissue

When energy is required, e.g. during periods of fasting, starvation or long-term exercise, NEFA are released from adipose TAG stores into the circulation by lipolysis and are subsequently oxidized, primarily by skeletal muscle, to provide energy ${ }^{(1)}$. Yet, adipose tissue also plays an important role in other physiological processes and it can be considered as an endocrine organ ${ }^{(2)}$. Adipocytes through the synthesis and release of peptide hormones by adipocytes, named adipokines ${ }^{(3)}$, are involved in the immune response, blood pressure control, haemostasis, bone mass, thyroid and reproductive function.

Fatty acids, apart from being an energy source, are involved in the transcriptional regulation of gene expression in adipose tissue and other tissues or organs ${ }^{(4-6)}$. NEFA also modulate gene transcription by exerting a direct, membraneindependent influence on the molecular events that govern gene expression ${ }^{(7)}$. Furthermore, it has been demonstrated that, compared to dietary fats rich in linoleic acid, fish oil increases insulin-stimulated glucose transport and metabolism in isolated white adipocytes ${ }^{(8)}$. The genes investigated in the present study are responsible for the trapping, release and storage of fatty acids, as well as being involved in glucose uptake and transduction of the insulin signal. PPAR $\gamma$ is a nuclear receptor with a major role in the regulation of adipocyte differentiation, lipid metabolism and insulin action ${ }^{(9,10)}$. In pigs the isoforms of PPAR $\gamma$ identified thus far include: PPAR $\gamma 1$ and PPAR $\gamma 2^{(11)}$. PPAR $\gamma 1$ has four transcription variants: PPAR $\gamma 1 \mathrm{a}, 1 \mathrm{~b}, 1 \mathrm{c}, 1 \mathrm{~d}^{(11)}$. The PPAR $\gamma$ coactivator 1 (PPARGC1A in pigs; also known as PGC-1) is a nuclearencoded transcriptional coactivator that plays a pivotal role in glucose metabolism, mitochondrial biogenesis, muscle fibre specialization and adaptive thermogenesis, and is a co-activator of PPAR $\gamma^{(12-14)}$. GLUT4 is an insulinresponsive glucose transporter and affects whole-body glucose homeostasis ${ }^{(8,15)}$. TNF $\alpha$ is a key modulator of adipocyte metabolism, with a direct role in several insulin-mediated processes, including glucose homeostasis and lipid metabolism ${ }^{(16)}$. Adiponectin is a factor exclusively secreted by adipose tissue that has been shown to exert anti-inflammatory

Abbreviations: ACTB, $\beta$-actin; f group, group supplemented with fish oil; FABP4, fatty acid binding protein 4; GAPDH, glyceraldehyde-3-phosphate dehydrogenase; HMBS, hydroxylmethylbilanesynthase; LEPR, leptin receptor; LPL, lipoprotein lipase; PPARGC1A, PPAR $\gamma$ coactivator 1A; s group, group supplemented with sunflower oil.

* Corresponding author: Dr Georgios A. Papadopoulos, fax +329 2647848, email georgios.papadopoulos@ugent.be 
and anti-atherogenic effects and reverse insulin resistance in rodents $^{(17)}$, by increasing insulin sensitivity ${ }^{(18)}$ through improvement of glucose and lipid metabolism ${ }^{(1)}$. Leptin is secreted principally, but not exclusively, by adipocytes and acts both centrally and peripherally, with a major role in the regulation of food uptake, body weight and energy balance ${ }^{(19)}$. It has been shown in gilts that acute changes in feed intake affect leptin secretion ${ }^{(20)}$. Fatty acid binding protein 4 (FABP4) functions to traffic fatty acids away from the TAG after hydrolysis ${ }^{(21)}$. Lipoprotein lipase (LPL) mainly has a function in hydrolysis of TAG, and although muscle LPL outweighs that of LPL in adipose tissue, the latter removes relatively more TAG in the postprandial period, making LPL of adipose tissue a prime target for metabolic regulation ${ }^{(22)}$. Meanwhile, relationships have been reported between the activation of PPAR $\gamma$ and the function of other genes, such as

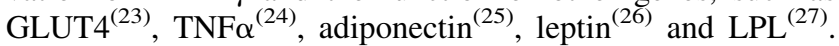
The relationship between circulating leptin and insulin with leptin mRNA and leptin receptor (LEPR) mRNA (also known as Ob-R1), respectively, have been investigated in growing pigs ${ }^{(28)}$. The nature of such relationships in lactating sows during the first days of lactation is not known yet.

The peri-parturient period in sows ${ }^{(29)}$ ranges from $4 \mathrm{~d}$ before to $3 \mathrm{~d}$ after parturition. The first days of lactation are of clinical importance, since the incidence of postpartum dysgalactia syndrome may occur until $72 \mathrm{~h}$ after parturition ${ }^{(30)}$. During pregnancy, sows are in an anabolic status, because they develop fetuses and mammary tissue. After farrowing, sows are in an anabolic (mammary gland) and a catabolic status, because body reserves (mainly adipose tissue) are mobilized to provide nutrients for milk production ${ }^{(31)}$. During early lactation in sows body reserves are more important determinants of milk yield than dietary intakes ${ }^{(32)}$. Therefore in the present study, samples of backfat adipose tissue of sows were taken at the first day of lactation, as it is the day of lactation closer to the transition period between pregnancy and lactation.

Information is limited regarding the effects of the $n-6: n-3$ ratio of the lactation diet of the sows and the prepartal feeding strategy on the abundance of expression of genes of backfat adipose tissue during this critical period. In addition, the interrelationships between PPAR $\gamma$ activation and function of genes involved in glucose and lipid metabolism, and between gene expression and levels of hormones in blood reflecting metabolism, during the same period, remain to be elucidated. The aim of the present study was to investigate the effect of two diets differing in $n-6: n-3$ ratio and fed from either 3 or $8 \mathrm{~d}$ before parturition onwards on the abundance of the genes involved in lipid and glucose metabolism in early lactation in sows. The relationships between PPAR $\gamma$ and its target genes, and between mRNA levels of genes and circulating hormones, were also investigated.

\section{Materials and methods}

\section{Study population and experimental design}

Seventy-two pregnant hybrid sows (Topigs 20 breed: Dutch Landrace $\times$ Great York) were included. Until day 107 of gestation, the sows were group-housed in a gestation unit and they were fed twice a day with a conventional gestation diet $(4 \mathrm{~kg} / \mathrm{d})$. The composition $(\mathrm{g} / \mathrm{kg})$ of the gestation feed was: DM 892; ash 67; crude protein 126; crude fat 34 ; neutral-detergent fibre 197; metabolizable energy $10400 \mathrm{~kJ} /$ $\mathrm{kg}$. Linoleic acid content was $11.53 \mathrm{~g} / \mathrm{kg}$, total $n-3$ PUFA was $1.66 \mathrm{~g} / \mathrm{kg}$, and DHA and EPA contents were fairly low: $4.09 \times 10^{-5}$ and $3.47 \times 10^{-5} \mathrm{~g} / \mathrm{kg}$, respectively.

At day 107 of gestation, the pregnant sows were moved to the farrowing crates, and they were randomly allocated using a $2 \times 2$ experimental design to four different treatment groups namely f3, f8, s3, s8. Sows from the $f$ and the s groups received a diet that was supplemented with fish oil or mainly sunflower oil, respectively. The compositions of the diets are shown in Table 1. Half of the sows belonging either to the f group or the s group received the experimental diet from day 107 of gestation (f8 and s8 groups) onwards ( $8 \mathrm{~d}$ before expected farrowing) until the end of lactation, the other half of the sows received the experimental diet from day 111 of gestation ( $\mathrm{f} 3$ and $\mathrm{s} 3$ group) onwards, being $3 \mathrm{~d}$ before the expected day of farrowing (onset day groups). The sows of the $\mathrm{f} 3$ group continued to receive the conventional gestation feed between days 107 and 111 of gestation. From day 107 of gestation onwards until farrowing, the sows from all four groups received the same amount of feed, namely $3.3 \mathrm{~kg} / \mathrm{sow}$ per d. A 3 -week batch production system was maintained, and the seventy-two sows farrowed in three consecutive batches of twenty-four sows each. Within each batch, the sows were randomly assigned to the four experimental groups. The mean parity of the sows between the experimental groups (f3 4.2; f8 4.4; s3 4.6; s8 4.3) was similar and not significantly different between groups $(P=0.570)$.

No feed was provided on the day of parturition (day 0 ). From the first day of lactation until weaning, the sows were fed twice a day at 08.00 and 18.00 hours. The amount of feed that was provided daily was $3.0 \mathrm{~kg}$ on days 1 and 2 , $3.5 \mathrm{~kg}$ on day $3,4.0 \mathrm{~kg}$ on days 4 and $5,4.5 \mathrm{~kg}$ on days 6

Table 1. Chemical composition of the two different feeds for the sows: the feeds were supplemented either with fish oil or with sunflower oil and differed in the $n-6: n-3$ ratio

\begin{tabular}{lcc}
\hline & \multicolumn{2}{c}{ Diet supplement } \\
\cline { 2 - 3 } & Fish oil & Sunflower oil \\
\hline Diet $(\mathrm{g} / \mathrm{kg})$ & & \\
DM & 899 & 886 \\
Ash & 65 & 65 \\
Crude protein & 171 & 167 \\
Crude fat & 61 & 61 \\
Neutral-detergent fibre & 181 & 181 \\
Metabolizable energy (kJ/kg) & 12300 & \\
Fatty acids (\% of total fatty acids) & & $26 \cdot 5$ \\
SFA & $33 \cdot 5$ & $29 \cdot 7$ \\
MUFA & $33 \cdot 4$ & $43 \cdot 3$ \\
PUFA & $33 \cdot 1$ & $38 \cdot 3$ \\
Total $n-6(\%$ of PUFA) & & $0 \cdot 2$ \\
$18: 2 n-6$ & $20 \cdot 9$ & \\
$20: 4 n-6$ & $0 \cdot 2$ & $2 \cdot 4$ \\
Total $n-3(\%$ of PUFA) & & $0 \cdot 3$ \\
$18: 3 n-3$ & $2 \cdot 1$ & $\mathrm{ND}$ \\
$18: 4 n-3$ & $1 \cdot 4$ & $0 \cdot 4$ \\
$20: 4 n-3$ & $0 \cdot 2$ & $0 \cdot 1$ \\
$20: 5 n-3$ & $2 \cdot 8$ & $0 \cdot 6$ \\
$22: 5 n-3$ & $0 \cdot 2$ & $10 \cdot 13$ \\
$22: 6 n-3$ & $3 \cdot 4$ & \\
$n-6: n-3$ & $2 \cdot 09$ & \\
& & \\
& &
\end{tabular}

ND, not detectable. 
and $7,5.0 \mathrm{~kg}$ on days 8 and 9 , and $5.5 \mathrm{~kg}$ from day 10 until day 21 (weaning). The amount of feed consumed by every sow was recorded daily from day 1 until day 21 .

The study was conducted at the Provimi Research Farm 'De Viersprong', Velddriel, The Netherlands and the experimental protocol of the study was approved by the Animal Sciences Group in Wageningen, The Netherlands.

\section{Sample collection and cDNA synthesis}

A biopsy of the backfat white adipose tissue of each of the seventy-two sows was taken on the first day of lactation, by using a spring-loaded biopsy instrument (Biotech PPB-U, Nitra, Slovakia) using a $10 \mathrm{~mm}$ cannula set at a depth of $2 \mathrm{~cm}$, as described previously ${ }^{(33)}$. The site of the biopsy was located $5 \mathrm{~cm}$ distal to the last rib to the side of the midline. Biopsies were collected immediately after the blood sampling procedure and before the morning meal from each sow at the first day of lactation.

For RNA preservation matters, the samples were immediately submerged in RNAlater (Sigma-Aldrich) according to the manufacturer's protocol and stored at $-20^{\circ} \mathrm{C}$ until they were crushed to powder with liquid nitrogen. The samples were subdivided per $80-100 \mathrm{mg}$ and stored at $-80^{\circ} \mathrm{C}$. Total RNA was extracted with the Aurum Total RNA Fatty and Fibrous Tissue Kit (Bio-Rad) according to the instructions manual, which also included an on-column DNase treatment. In order to check the RNA integrity by evaluating the $28 \mathrm{~S}$ and $18 \mathrm{~S}$ ribosomal RNA bands, RNA was loaded on to a $0.8 \%$ agarose gel. Next, a minus reverse transcription control PCR (with the YWHAZ primers ${ }^{(34)}$, which included a positive porcine genomic DNA control and a no-template control, was performed to check if any DNA contamination was still present. After this, the purity and concentration of the RNA were measured with the ND-1000 spectrophotometer (NanoDrop). The samples showed an optical density $260 / 280$ ratio between 1.75 and 2.10 and an RNA concentration of $24-40 \mathrm{ng} / \mu \mathrm{l}$ with a total yield of $0.72-1.2 \mu \mathrm{g}$ RNA. By means of a $20 \mu l$ reverse transcription reaction with the iScript cDNA synthesis kit (Bio-Rad), approximately $0.8 \mu \mathrm{g}$ RNA from each sample was converted to cDNA. A verification of the reverse transcription reaction was performed through a control PCR (with the same YWHAZ primers as for the minus reverse transcription control) using $2.5 \mu l$ cDNA (diluted ten times with 2-amino-2-hydroxymethyl-1,3-propanediol hydrochloride buffer, $\mathrm{pH} 8,10 \mathrm{~mm}$ ). To check for DNA contamination, every PCR included a no-template control.

\section{Primers}

Primers for reference gene selection (ACTB, B2M, GAPDH, HMBS, HPRT1, RPL13A, SDHA, TBP, TOP2B, YWHAZ) for normalization of real-time PCR mRNA expression data were used from Erkens et al. ${ }^{(34)}$. The National Center for Biotechnology Information database ${ }^{(35)}$ and literature was searched for available porcine sequences and primers of the genes under investigation $^{(36,37)}$ (Table 2). Primers were designed using Primer $3^{(38)}$, while amplicon specificity of the primers was checked with Blast ${ }^{(39)}$ and possible secondary structures of the amplicon were verified with Mfold ${ }^{(40)}$. During optimization, the optimal concentration and annealing temperature for each primer were determined. Also, each amplicon was verified by sequencing.

\section{Reference gene selection and $m R N A$ expression analysis}

Determination of the most stable reference genes and their number to be used for normalization of real-time mRNA expression data was done as described previously ${ }^{(34)}$ by using the geNorm algorithm ${ }^{(41)}$, on twenty-four randomly selected samples from all four groups of sows. PCR efficiencies for the

Table 2. Forward and reverse primers used for PPAR $\gamma 1 \mathrm{a} / 1 \mathrm{~b}, \gamma 1 \mathrm{c} / 1 \mathrm{~d}$ and PPAR $\gamma 2$, PPARGC1A, lipoprotein lipase (LPL), GLUT4, fatty acid binding protein 4 (FABP4), $\mathrm{TNF}_{\alpha}$, adiponectin, leptin and leptin receptor (LEPR), amplicon length, annealing temperatures determined for each primer, and GenBank accession number or reference

\begin{tabular}{|c|c|c|c|c|}
\hline Gene & Primer sequence $\left(5^{\prime} \rightarrow 3^{\prime}\right)$ & Amplicon length (bp) & Annealing temperature $\left({ }^{\circ} \mathrm{C}\right)$ & GenBank accession no. or reference \\
\hline Adiponectin & $\begin{array}{l}\text { TCTGGCTCTGTGCTCCTCT } \\
\text { GACCCCATTATTCTCTTCATCC }\end{array}$ & 81 & 60 & EU076587 \\
\hline FABP4 & $\begin{array}{l}\text { GAAGTGGGAGTGGGCTTT } \\
\text { TTATGGTGCTCTTGACTTTCCT }\end{array}$ & 190 & 60 & EU076588 \\
\hline GLUT4 & $\begin{array}{l}\text { CTTGTCCTCGCCGTCTTCT } \\
\text { GCTCTGTTCAATCACCTTCTGG }\end{array}$ & 96 & 60 & EU076589 \\
\hline LEPR & $\begin{array}{l}\text { TTTGGACAGAGCAAGCACA } \\
\text { AGAGCAGCCAGGAAAGACC }\end{array}$ & 171 & 60 & EU076590 \\
\hline Leptin & $\begin{array}{l}\text { GCACGACACCAAAGACAGA } \\
\text { GCTGGAGATGGAACAGGAA }\end{array}$ & 123 & 60 & EU076591 \\
\hline LPL & $\begin{array}{l}\text { GGAGAGAGGAAGGGAAAACAGA } \\
\text { AGGGAAAAGACCGACCAATAAA }\end{array}$ & 157 & 60 & EU076592 \\
\hline PPAR $\gamma 1 \mathrm{a} / 1 \mathrm{~b}$ & $\begin{array}{l}\text { GCGCTCGGGTCGGCCGC } \\
\text { GAGCTGATCCCAAAGTTGGT }\end{array}$ & $\begin{array}{l}186(1 a) \\
112(1 b)\end{array}$ & 60 & Omi et al. ${ }^{(11)}$ \\
\hline PPAR $\gamma 1 \mathrm{c} / 1 \mathrm{~d}$ & $\begin{array}{l}\text { GGCCTTTACCTCTGCTGGTA } \\
\text { GAGCTGATCCCAAAGTTGGT }\end{array}$ & $\begin{array}{l}200(1 c) \\
126(1 d)\end{array}$ & 61 & Omi et al. ${ }^{(11)}$ \\
\hline PPAR $\gamma 2$ & $\begin{array}{l}\text { AGCAAACCCCTATTCCATGC } \\
\text { GAGCTGATCCCAAAGTTGGT }\end{array}$ & 161 & 60 & Omi et al. ${ }^{(11)}$ \\
\hline PPARGC1A & $\begin{array}{l}\text { CCTGCATGAGTGTGTGCTCT } \\
\text { CTCAGAGTCCTGGTTGCACA }\end{array}$ & 107 & 59 & Jacobs et al. ${ }^{(36)}$ \\
\hline $\mathrm{TNF} \alpha$ & $\begin{array}{l}\text { CTCTTCTGCCTACTGCACTTCG } \\
\text { GATGATCTGAGTCCTTGGGC }\end{array}$ & 101 & 57 & Jung et al. ${ }^{(37)}$ \\
\hline
\end{tabular}


reference genes ranged between 90 and $104 \%$. The mRNA expression for each of the genes in Table 2 was determined by real-time PCR with Platinum SYBR Green qPCR Supermix UDG (Bio-Rad) on the iCycler iQ Real-Time PCR Detection System (Bio-Rad) and subsequently normalized, as described in Erkens et al. ${ }^{(34)}$. PCR efficiencies were between 91 and $103 \%$.

\section{Blood parameters analysis}

Blood was collected on the first day of lactation by jugular venepuncture. Parameters such as leptin, insulin and thyroid hormones were analysed in serum. Leptin was determined using a commercially available RIA test kit (Multi-Species Leptin RIA Kit, catalogue number XL-85K; Linco Research Inc., St. Charles, MO, USA). Insulin was analysed by the Biosource INS-IRMA KIP1251-KIP1254 method. Thyroid hormones (T3 and T4) were analysed by using a specific RIA.

\section{Statistical analyses}

All examined parameters were analysed for the four experimental groups with two-way ANOVA. The type of feed ( $\mathrm{f} v . \mathrm{s}$ ) and the duration of providing the experimental feed (onset day $3 v$. onset day 8 before farrowing) were included as fixed factors in the models. When the interaction of diet type and onset day was significant, further comparisons between the four experimental groups were performed using a post-hoc Duncan test. Mean values and their standard errors were calculated for each experimental group separately (f3; f8; s3; s8). Correlations between the examined parameters (expression of genes, blood parameters) were investigated using Spearman rank correlations. The level of significance was at $P \leq 0.05$ (two-sided test). All statistical analyses were performed using SPSS 15.0 (SPSS Inc., Chicago, IL, USA).

\section{Results}

\section{Reference gene selection}

Analysis of the real-time data indicated that RPL13A was not suitable as a reference gene because it could not be detected in all samples. The application of the geNorm algorithm to the mRNA expression data of the other nine reference genes indicated that it was sufficient to use a set of the three most stably expressed reference genes for normalization. As can be seen in Fig. 1, these genes are hydroxylmethylbilanesynthase (HMBS), glyceraldehyde-3-phosphate dehydrogenase (GAPDH) and $\beta$-actin (ACTB).

Effect of n-6:n-3 ratio and prepartal feeding strategy on gene expression

The mRNA expression of the genes in the adipose tissue of the sows during the first day of lactation is shown in Figs. 2 and 3. No significant differences were found in mRNA levels of PPAR $\gamma 1 \mathrm{c} / \mathrm{d}, \operatorname{PPAR} \gamma 1 \mathrm{a} / \mathrm{b}, \mathrm{GLUT} 4$, adiponectin, leptin, LEPR, LPL, FABP4 and TNF $\alpha$. A significant interaction of diet type $\times$ onset day was found for PPAR $\gamma 2$ and PPARGC1A mRNA levels $(P=0.019$ and $P=0.012$, respectively), with the $\mathrm{f} 3$ sows showing lower mRNA expression than $\mathrm{s} 3$ and $\mathrm{f} 8$ for PPAR $\gamma 2$, and lower than $s 3$ for PPARGC1A.

Correlations between mRNA expression of PPAR $\gamma$ isoforms and PPAR y coactivator 1A, lipoprotein lipase, GLUT4, fatty acid binding protein $4, T N F \alpha$, adiponectin, leptin and leptin receptor

The correlations between the mRNA levels of the genes investigated in the present study are listed in Table 3. PPAR $\gamma 1 \mathrm{c} / \mathrm{d}$ levels correlated with the levels of all genes except for PPARGC1A and LEPR. PPAR $\gamma 1 \mathrm{a} / \mathrm{b}$ correlated with the

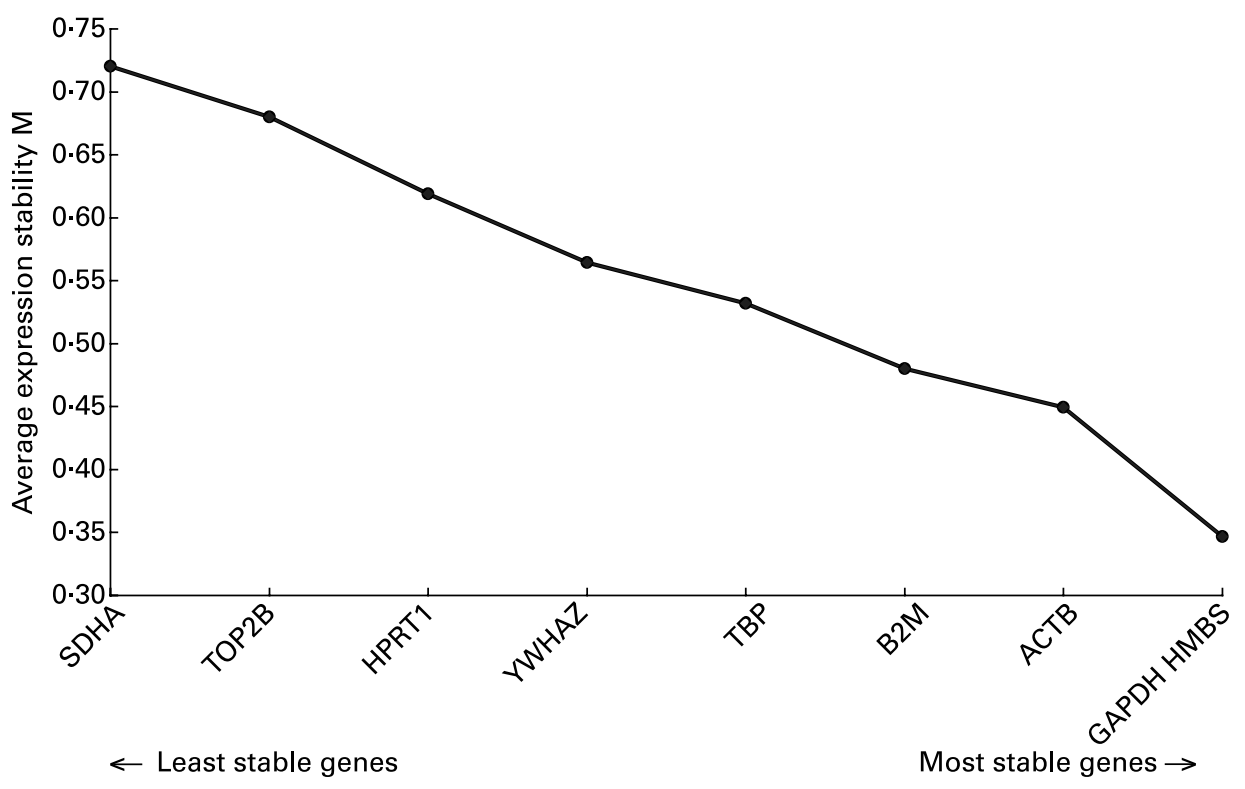

Fig. 1. Stability of the reference genes, calculated by geNorm. $M$ value indicates the expression stability of the reference genes ${ }^{(34)}$. Higher $M$ corresponds with lower stability. ACTB, $\beta$-actin; B2M, $\beta$-2-microglobulin; GAPDH, glyceraldehyde-3-phosphate dehydrogenase; HMBS, hydroxylmethylbilanesynthase; HPRT1, hypoxanthinephosphoribosyltransferase 1; SDHA, succinate dehydrogenase complex subunit A; TBP, TATA box binding protein; TOP2B, topoisomerase II $\beta$; YWHAZ, tyrosine 3-monooxygenase/tryptophan 5-monooxygenase activation protein zeta polypeptide. 
(A)

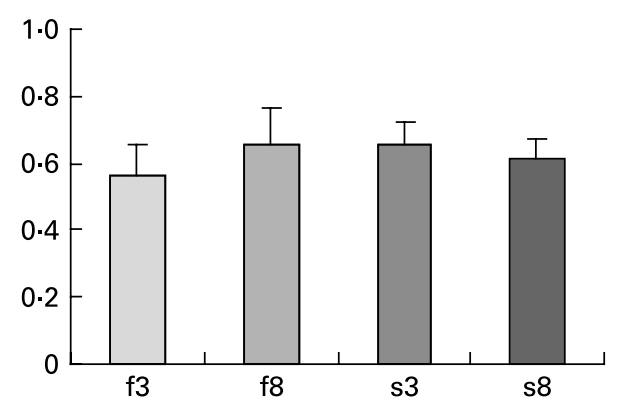

(C)

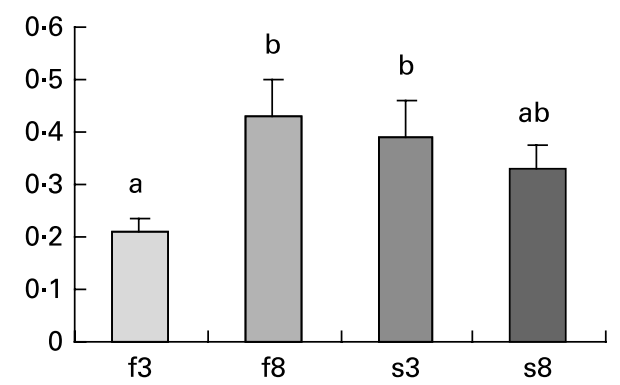

(B)

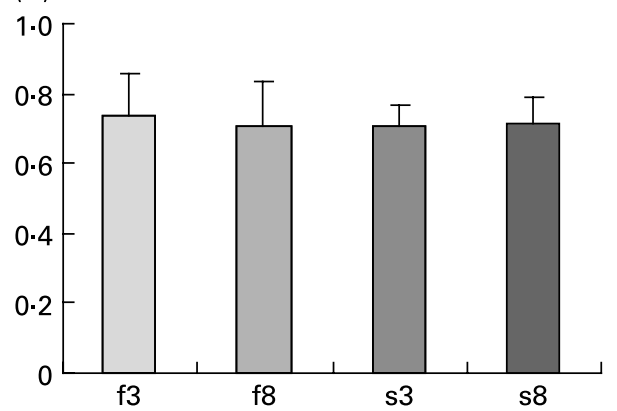

(D)

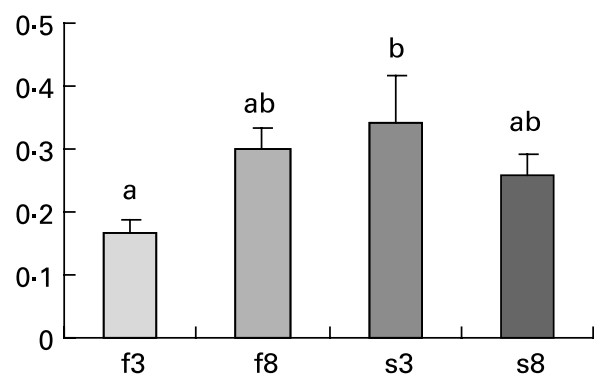

Fig. 2. PPAR $\gamma 1 \mathrm{c} / \mathrm{d}(\mathrm{A}), \mathrm{PPAR} \gamma 1 \mathrm{a} / \mathrm{b}(\mathrm{B}), \mathrm{PPAR} \gamma 2(\mathrm{C})$ and PPAR $\gamma$ coactivator $1 A(\mathrm{D}) \mathrm{mRNA}$ levels in white adipose tissue from sows fed two lactation diets differing in the $n-6: n-3$ ratio: low, supplemented with fish oil (f diet type); high, supplemented with sunflower oil (s diet type). The diets were administered from two time-points onwards: 8 or $3 \mathrm{~d}$ before farrowing (onset day group 8 or 3 ) (f3, f diet type, onset day 3 ; f8, f diet type, onset day 8 ; s3, s diet type, onset day 3 ; s8, s diet type, onset day 8). The mRNA abundance for each of the genes was measured by real-time PCR on the iCycler iQ Real-Time PCR Detection System (Bio-Rad) and subsequently normalized. Values are means with their standard errors depicted by vertical bars. ${ }^{\text {a,b }}$ Mean values with unlike superscripts were significantly different $(P<0 \cdot 05)$.

levels of all genes except for PPARGC1A. PPAR $\gamma 2$ correlated with the levels of all genes except for LEPR.

Correlations between $m R N A$ expression of PPAR $\gamma$ isoforms and PPAR y coactivator 1A, lipoprotein lipase, GLUT4, fatty acid binding protein 4, TNF $\alpha$, adiponectin, leptin and leptin receptor with circulating leptin, insulin and thyroid hormones

Circulating leptin was negatively correlated with mRNA levels of adiponectin $(r-0.326, P=0.006)$, LEPR $(r-0.276$, $P=0.027)$ and LPL $(r-0.341, P=0.005)$. T3 was negatively correlated with mRNA levels of FABP4 $(r-0 \cdot 249, P=0 \cdot 047)$ and T4 with mRNA levels of PPARGC1A $(r 0.264, P=0.038)$. No significant correlation was found for insulin (e.g. with GLUT4, $r$ 0.083, $P=0 \cdot 556$ ).

\section{Discussion}

The present study investigated the effect of two peripartal diets differing in $n-6: n-3$ ratio, and fed from either 3 or $8 \mathrm{~d}$ before parturition, on the abundance of genes involved in lipid and glucose metabolism in early lactation. Biopsies were collected on the first day of lactation, after blood sampling and before sows received a morning meal. Information regarding sows in this field is scarce. In growing pigs samples of adipose tissue for analysis of leptin and LEPR mRNA expression were collected after blood sampling ${ }^{(28)}$. In dogs, biopsies of adipose tissue and skeletal muscle were collected in a fasted state as in the present study ${ }^{(42)}$. Fasted state for collection of samples seemed to be the most appropriate as it has been shown in sows that differences in parameters in plasma, such as glucose, NEFA and insulin, occur before and after feeding ${ }^{(43)}$.

The three most stable reference genes used for normalization of the mRNA expression data of the genes under investigation in the present experiment were HMBS, GAPDH and ACTB. Also in a previous experiment on porcine muscle and fat ${ }^{(34)}$, ACTB belonged to the most stable reference genes. However, in the latter experiment ${ }^{(34)}$, GAPDH proved to be the most unstable reference gene, not suitable for normalization purposes. This shows once again that even in the same tissue type the stability of a reference gene can vary between different experiments and that the expression stability of the reference genes to be used for normalization of real-time relative mRNA expression data should be evaluated for each experiment separately.

The differences observed in PPAR $\gamma 2$ and PPARGC1A mRNA expression might indicate a higher susceptibility to the dietary manipulation at $1 \mathrm{~d}$ postpartum of these genes in comparison to the other members of the PPAR $\gamma$ family. The decrease in PPAR $\gamma 2$ and PPARGC1A mRNA expression by the high $n-6: n-3$ when fed from $3 \mathrm{~d}$ prepartum corresponds with evidence from the literature that $n-6$ and $n-3$ fatty acids act as ligands for the PPAR $\gamma$, and as found in the human thromboplast cell line, BeWo, the transcription factors PPAR $\gamma$ were reduced after incubation with $n-3$ PUFA $^{(44)}$. Other studies also confirmed that PPAR $\gamma$ levels appeared to be increased more by $n-6$ fatty acids than $n-3$ fatty acids ${ }^{(45,46)}$. Furthermore, PPAR $\gamma 2$ has been identified as a form that functions in adipocyte differentiation through gene 

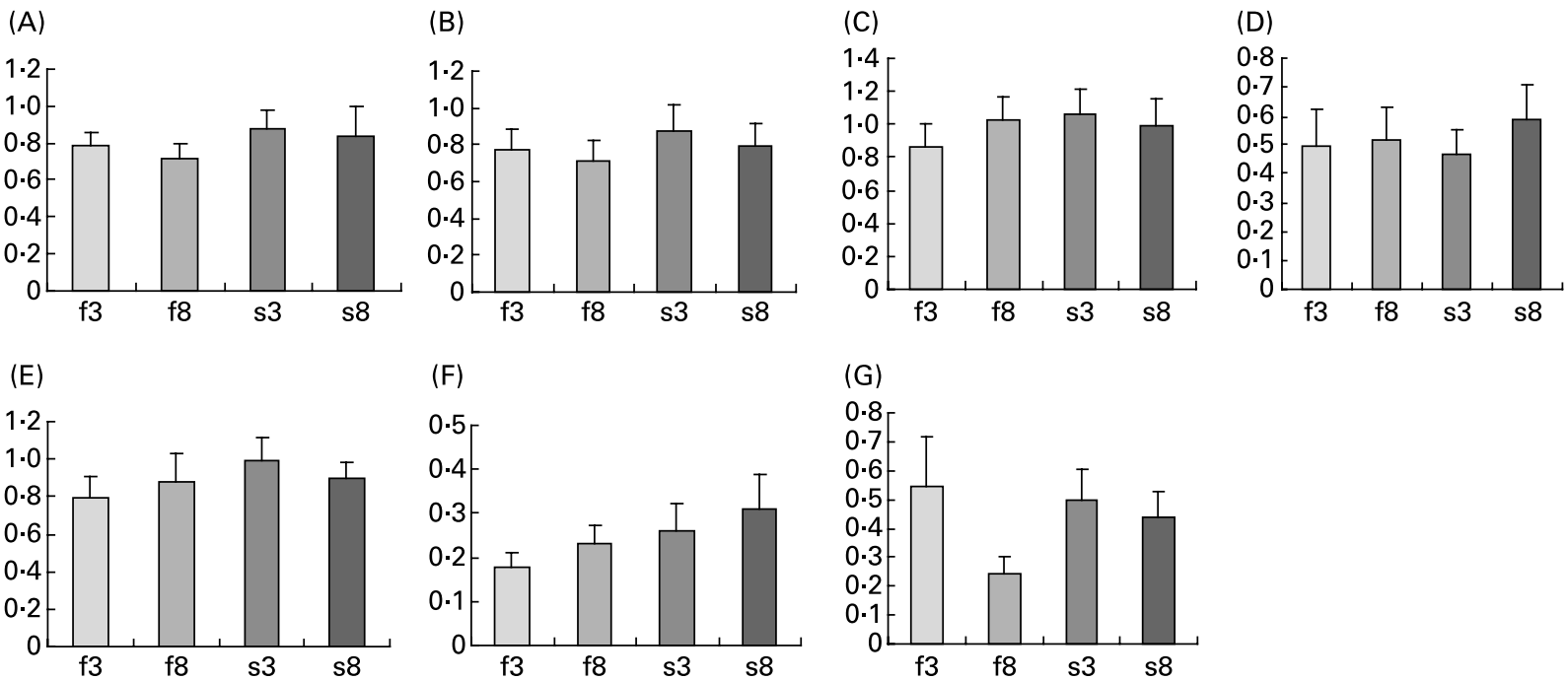

Fig. 3. GLUT4 (A), adiponectin (B), leptin (C), leptin receptor (D), TNF $\alpha(E)$, lipoprotein lipase (F) and fatty acid binding protein $4(G)$ mRNA levels in white adipose tissue from sows fed two lactation diets differing in the $n-6: n-3$ ratio: low, supplemented with fish oil (f diet type); high, supplemented with sunflower oil (s diet type). The diets were administered from two time-points onwards: 8 or $3 \mathrm{~d}$ before farrowing (onset day group 8 or 3 ) ( $f 3$, $f$ diet type, onset day 3 ; f8, $f$ diet type, onset day 8; s3, s diet type, onset day 3; s8, s diet type, onset day 8). The mRNA abundance for each of the genes was measured by real-time PCR on the iCycler iQ Real-Time PCR Detection System (Bio-Rad) and subsequently normalized. Values are means with their standard errors depicted by vertical bars. No significant differences were found.

regulation $^{(47-50)}$ and perhaps this function may explain its sensitivity to the $n-6: n-3$ ratio and the acute feed changes prior to parturition. Moreover, a critical aspect of the PPARGC1 co-activators is that they are highly versatile and have the ability to interact with many different transcription factors. In doing so, they activate distinct biological programmes in different tissues ${ }^{(51)}$

In the human thromboplast cell line (BeWo), $n$-3 PUFA had a dose- and time-dependent effect on leptin expression ${ }^{(44)}$. Sows in the present study were offered equal amounts of isoenergetic diets. The increase in energy intake at the change of the gestation diet to the experimental diet (type lactation diet) induced changes in circulating leptin levels in the present study (reported elsewhere). Yet, at the day of the biopsies, no significant differences were found in circulating leptin and

Table 3. Correlations ( $r$ Spearman rank) between mRNA levels of three isoforms of PPAR $\gamma$ and other genes in the adipose tissue of sows $\dagger$

\begin{tabular}{|c|c|c|c|}
\hline & PPAR $\gamma 1 \mathrm{c} / \mathrm{d}$ & PPAR $\gamma 1 \mathrm{a} / \mathrm{b}$ & PPAR $\gamma 2$ \\
\hline PPAR $\gamma 1 \mathrm{c} / \mathrm{d}$ & & $0.787^{\star \star \star}$ & $0.752^{\star \star \star}$ \\
\hline PPAR $\gamma 1 \mathrm{a} / \mathrm{b}$ & $0.787^{\star \star *}$ & & $0.698^{\star * *}$ \\
\hline PPAR $\gamma 2$ & $0.752^{\star * \star}$ & $0.698^{\star * \star}$ & \\
\hline PPARGC1A & 0.222 NS & $0.169 \mathrm{NS}$ & $0.273^{*}$ \\
\hline Adiponectin & $0 \cdot 316^{\star *}$ & $0.615^{\star \star \star}$ & $0.416^{\star * *}$ \\
\hline GLUT4 & $0.483^{\star \star \star}$ & $0.444^{\star \star \star}$ & $0.523^{\star \star \star}$ \\
\hline Leptin & $0.405^{\star *}$ & $0.414^{\star \star *}$ & $0.573^{* * *}$ \\
\hline LEPR & $0.134 \mathrm{NS}$ & $0.299^{\star}$ & 0.182 NS \\
\hline LPL & $0.406^{\star \star}$ & $0.582^{\star \star \star}$ & $0.488^{\star \star \star}$ \\
\hline FABP4 & $0.367^{\star *}$ & $0.585^{\star \star \star}$ & $0.366^{\star \star}$ \\
\hline $\mathrm{TNF} \alpha$ & $0.469^{\star \star \star}$ & $0.654^{\star \star \star}$ & $0.584^{\star * *}$ \\
\hline
\end{tabular}

Correlation coefficients were significant: ${ }^{\star} P<0.05$, ${ }^{\star \star} P<0.01$, ${ }^{\star \star \star} P<0.001$.

† Sows received two lactation diets differing in the $n-6: n-3$ ratio (a low $v$. a high) and were administered from two time-points onwards before parturition ( 8 or $3 \mathrm{~d}$ ). The mRNA abundance for each of the genes was measured by real-time PCR on the iCycler iQ Real-Time PCR Detection System (Bio-Rad) and subsequently normalized. The correlations represent the results from all treatment groups together (global data)
LEPR mRNA expression. In growing pigs, dietary oil sources did not change plasma leptin and insulin concentrations, whereas the main effect of oil sources and adipose tissue sources were significant for leptin mRNA and LEPR mRNA expression $^{(28)}$. This suggests that leptin mRNA expression in white adipose tissue of growing pigs was affected by an insulin-independent mechanism. Furthermore, fish oil supplementation in growing pigs decreased the abundance of leptin mRNA and LEPR mRNA compared with soyabean oil, in the dorsal subcutaneous adipose tissue ${ }^{(28)}$. However, in the present study, during the first day of lactation, insulin levels were significantly affected by the type of fat (reported elsewhere), whereas leptin mRNA and LEPR mRNA were not affected by the type of fat source. This difference may indicate different regulations of these parameters between growing pigs and lactating sows, but the lack of effect of the type of diet on leptin mRNA and LEPR mRNA expression might also indicate that these parameters are insulin-independent in lactating sows.

Arachidonic acid, a member of the $n-6$ PUFA, enhances either the translocation of both major adipocyte glucose transporters (GLUT4 and GLUT1) to the plasma membrane or reduces their rate of internalization ${ }^{(52)}$, and in 3T3-L1 adipocytes, arachidonic acid regulated GLUT4 gene expression by potentially two independent mechanisms: (1) via oxidative metabolism to the cyclooxygenase metabolite PGE2 and the subsequent elevation of cAMP levels (2) via non-oxidized fatty acid with the potential involvement of a PPAR ${ }^{(53)}$. A possible explanation for the absence of significant effects on GLUT4 levels in the present study is that in the biopsies of adipose tissue collected from sows, total cellular mRNA expression of GLUT4 was measured, leaving the question whether the $n-6: n-3$ ratio affected GLUT4 translocation. It is known that reduced glucose transport activity could be the result of fatty acid effects on the GLUT4 transporter directly, i.e. alterations in the trafficking, budding, fusion or activity of GLUT4, or it could result from fatty acid-induced alterations 
in upstream insulin signalling events, resulting in decreased GLUT4 translocation to the plasma membrane ${ }^{(54)}$.

Findings from studies in man and in experimental animals suggested that mRNA levels in adipose tissue of adiponectin ${ }^{(55)}, \mathrm{TNF}^{(16)}, \mathrm{FABP}^{(56)}$ and $\mathrm{LPL}^{(57,58)}$ are either influenced by the dietary fat source or they are involved in the regulation of lipid metabolism. In the present study no significant differences were found in the expression levels of these genes. The different metabolism dynamics around parturition may make a major difference too. Yet it cannot be excluded that differences between dietary groups on expression of these genes occurred either earlier or later than $1 \mathrm{~d}$ postpartum. Studies in man ${ }^{(59,60)}$, rodents ${ }^{(61)}$ and dogs ${ }^{(42)}$ provided evidence for differences in mRNA expression between various fat depots of the body. In the present study, adipose tissue was collected only from one position in the backfat adipose tissue in lactating sows, to limit the effect of the induced stress on the metabolism and performance of the sows. The level of inclusion of the fat sources was $2 \%$, in order to introduce a diet that is closer to the levels of inclusion used in practice, but especially to avoid negative effects associated with higher supplementation of fish oil ${ }^{(62-64)}$.

Significant correlations between the mRNA expressions of the genes investigated in the present study were also observed in other animal models. It is known that the target genes of PPAR $\gamma$ encode proteins involved in the trapping, release and storage of fatty acids, such as FABP ${ }^{(65)}$, LPL $^{(27)}$, leptin ${ }^{(26,42)}$, $\mathrm{TNF}^{(24)}$, adiponectin ${ }^{(25,42,55,66)}$ and GLUT4 ${ }^{(67)}$. Circulating leptin was inversely related to the LEPR mRNA expression, and no correlation was found between circulating leptin and leptin mRNA expression. Divergences between circulating leptin and leptin gene expression were reported previously in $\operatorname{man}^{(68)}$ and in obese women ${ }^{(69)}$, in which changes in circulating leptin did not depend on the synthesis of new protein, suggesting that leptin in man was released from a preformed pool within the cells and post-transcriptional regulation of leptin might occur. Another reason for the divergences observed between circulating leptin and leptin mRNA expression in lactating sows is the fact that leptin may be transferred from the maternal circulation to the milk as in rats ${ }^{(70)}$. In addition, it was found in lactating sows that milk concentrations of leptin were not correlated with backfat thickness or serum levels of leptin ${ }^{(71)}$. The existence of a positive relationship between T4 and PPARGC1A may be explained by the fact that thyroid hormones stimulate mitochondrial biogenesis and induce mitochondrial genes encoded in the nucleus ${ }^{(72)}$. Also the role of PPARGC1A in the regulation of mitochondrial oxidative metabolism is important, as the loss of PPARGC1A leads to significant functional deficits in oxidative metabolism in multiple tissues and renders mice exercise intolerant ${ }^{(73)}$.

In conclusion, adipocyte PPAR $\gamma 2$ and PPARGC1A mRNA expression in sows at $1 \mathrm{~d}$ postpartum depends on the prepartum dietary $n-6: n-3$ ratio in combination with the onset of prepartum feeding plane during late gestation. This suggests that the effect of dietary fatty acid profile on the regulation of these genes on biopsies of backfat adipose tissue of sows taken at the first day of lactation is modulated by the duration of the feeding plane during the last week of gestation. The present findings and the emergence of PPAR $\gamma 2$ as a key modulator of the expression of genes that are critically involved in glucose and lipid metabolism and the role of PPARGC1A as a co-activator may help to elucidate the pathophysiology basis of metabolic-associated problems during the first stages of lactation in sows.

\section{Acknowledgements}

Expenses for the laboratory analyses were covered by the scholarship programme awarded to G. A. P. by the Greek State Scholarship Foundation for postgraduate study abroad (www.iky.gr). G. A. P. was responsible for the study design, study performance, parameters analysis, data analysis and manuscript drafting. T. E. contributed equally to this study, and performed the mRNA expression analysis and contributed to manuscript drafting. L. J. P. supervised the mRNA expression analysis and contributed to manuscript drafting. T. A. T. G. v. K. was responsible for supervision of logistic arrangements, experimental diet development and contributed to manuscript drafting. J. B. supervised the analysis of blood parameters and contributed to manuscript drafting. D. G. D. M. and G. P. J. J. evaluated the study design, contributed to data analysis and manuscript drafting, and both are promoters of G. A. P. Maria D. Baucells from the Departament de Ciència Animal i dels Aliments, Universitat Autònoma de Barcelona is acknowledged for the provision of the biopsy device. It is declared by the corresponding author that no conflict of interest exists for this paper.

\section{References}

1. Arner P (2003) The adipocyte in insulin resistance: key molecules and the impact of the thiazolidinediones. Trends Endocrinol Metab 14, 137-145.

2. Trayhurn P \& Beattie JH (2001) Physiological role of adipose tissue: white adipose tissue as an endocrine and secretory organ. Proc Nutr Soc 60, 329-339.

3. Trayhurn P (2005) Endocrine and signalling role of adipose tissue: new perspectives on fat. Acta Physiol Scand 184, 285-293.

4. Duplus E, Glorian M \& Foresti C (2000) Fatty acid regulation of gene transcription. J Biol Chem 275, 30749-30752.

5. Jump DB \& Steven DC (1999) Regulation of gene expression by dietary fat. Annu Rev Nutr 19, 63-90.

6. Hihi AK, Michalik L \& Wahli W (2002) PPARs: transcriptional effectors of fatty acids and their derivatives. Cell Mol Life Sci 59, 790-798.

7. Armoni M, Harel C \& Karnieli E (2007) Transcriptional regulation of the GLUT4 gene: from PPAR-g and FOXO1 to FFA and inflammation. Trends Endocrinol Metab 18, 100-107.

8. Ezaki O, Tsuji E, Momomura K, Kasuga M \& Itakura H (1992) Effect of fish and safflower oil feeding on subcellular glucose transporter distributions in rat adipocytes. Am J Physiol 263, E94-E101.

9. Tanaka T, Itoh H, Doi K, et al. (1999) Down regulation of peroxisome proliferator-activated receptor $\mathrm{g}$ expression by inflammatory cytokines and its reversal by thiazolidinediones. Diabetologia 42, 702-710.

10. Walczak R \& Tontonoz P (2002) PPARadigms and PPARadoxes. Expanding roles for PPAR $\gamma$ in the control of lipid metabolism. J Lipid Res 43, 177-186.

11. Omi T, Brenig B, Špilar Kramer Š, Iwamoto S, Stranzinger G \& Neuenschwander S (2005) Identification and characterization of novel peroxisome proliferator-activated receptor-gamma (PPAR- $\gamma$ ) transcriptional variants in pig and human. J Anim Breed Genet 122, 45-53. 
12. Knutti D \& Kralli A (2001) PGC-1, a versatile coactivator. Trends Endocrinol Metab 12, 360-365.

13. Lin J, Wu H, Tarr PT, Zhang CY, Wu Z, Boss O, Michael LF, Puigserver P, Isotani E, Olson EN, Lowell BB, Bassel-Duby R \& Spiegelman BM (2002) Transcriptional co-activator PGC-1a drives the formation of slow-twitch muscle fibres. Nature 418, 797-801.

14. Yoon JC, Puigserver P, Chen G, et al. (2001) Control of hepatic gluconeogenesis through the transcriptional coactivator PGC-1. Nature 413, 131-138.

15. Kahn BB (1994) Dietary regulation of glucose transporter gene expression: tissue specific effects in adipose cells and muscle. J Nutr 124, 1289S-1295S.

16. Sethi JK \& Hotamisligil GS (1999) The role of TNF $\alpha$ in adipocyte metabolism. Semin Cell Dev Biol 10, 19-29.

17. Yamauchi T, Kamon J, Waki H, et al. (2001) The fat-derived hormone adiponectin reverses insulin resistance associated with both lipoatrophy and obesity. Nat Med 7, 941-946.

18. Hu E, Liang P \& Spiegelman BM (1996) AdipoQ is a novel adipose-specific gene dysregulated in obesity. J Biol Chem 271, 10697-10703.

19. Trayhurn P, Hoggard N, Mercer JG \& Rayne DV (1999) Leptin: fundamental aspects. Int $J$ Obes Relat Metab Disord 23, Suppl. 1, S22-S28.

20. Whisnant CS \& Harrell RJ (2002) Effect of short-term feed restriction and refeeding on serum concentrations of leptin, luteinizing hormone and insulin in ovariectomized gilts. Domest Anim Endocrinol 22, 73-80.

21. Vogel Hertzel A \& Bernlohr DA (2000) The mammalian fatty acid-binding protein multigene family: molecular and genetic insights into function. Endocrinol Metab 11, 175-180.

22. Frayn KN (1996) Integration of carbohydrate, fat and protein metabolism in the whole body. In Metabolic Regulation: A Human Perspective, pp. 103-140 [K Snell, editor]. London: Portland Press.

23. Dana SL, Hoener PA, Bilakovics JM, Crombie DL, Ogilvie KM, Kauffman RF, Mukherjee R \& Paterniti JR (2001) Peroxisome proliferator-activated receptor subtype-specific regulation of hepatic and peripheral gene expression in the Zucker diabetic fatty rat. Metabolism 50, 963-971.

24. Miles PD, Romeo OM, Higo K, Cohen A, Rafaat K \& Olefsky JM (1997) TNF-alpha-induced insulin resistance in vivo and its prevention by troglitazone. Diabetes 46, 1678-1683.

25. Maeda N, Takahashi M, Funahashi T, et al. (2001) PPARgamma ligands increase expression and plasma concentrations of adiponectin, an adipose-derived protein. Diabetes $\mathbf{5 0}$, 2094-2099.

26. Cohen B, Novick D \& Rubinstein M (1996) Modulation of insulin activities by leptin. Science 274, 1185-1188.

27. Schoonjans K, Peinado-Onsurbe J, Lefebvre AM, Heyman RA, Briggs M, Deeb S, Staels B \& Auwerx J (1996) PPAR $\alpha$ and PPAR $\gamma$ activators direct a distinct tissue-specific transcriptional response via a PPRE in the lipoprotein lipase gene. EMBO J 15, $5336-5348$.

28. Xingjie C, Defa L, Jingdong Y, Yuhua D, Heliang Z, Huawei Z \& Ganfeng Y (2006) Regulation of dietary energy level and oil source on leptin and its long form receptor mRNA expression of the adipose tissues in growing pigs. Domest Anim Endocrinol 31, 269-283.

29. Nachrein RF (1972) Gestational and periparturient periods of sows - serum chemical, hematologic, and clinical changes during the periparturient period. Am J Vet Res 33, $2233-2238$.

30. Klopfenstein C, Farmer C \& Martineau GP (2006) Diseases of the mammary glands. In Diseases of Swine, 9th ed. pp. 57-74 [BE Straw, JJ Zimmerman, SD' Allaire and DJ Taylor, editors]. Oxford: Blackwell Publishing.
31. Mullan BP \& Williams IH (1990) The chemical composition of sows during their first lactation. Anim Prod 51, 375-387.

32. Mullan BP \& Williams IH (1989) The effect of body reserves at farrowing on the reproductive performance of first-litter sows. Anim Prod 48, 449-457.

33. Craven J, Hernessy DR \& Friis C (2002) Does the rate of fat deposition influence the pharmacokinetic disposition of subcutaneously administered moxidectin and ivermectin in pigs? $J$ Vet Pharmacol Ther 25, 351-357.

34. Erkens T, Van Poucke M, Vandesompele J, Goossens K, Van Zeveren A \& Peelman LJ (2006) Development of a new set of reference genes for normalization of real-time RT-PCR data of porcine backfat and longissimus dorsi muscle, and evaluation with PPARGC1A. BMC Biotechnol 6, 41.

35. National Center for Biotechnology Information. http://www. ncbi.nlm.nih.gov

36. Jacobs K, Rohrer G, Van Poucke M, Piumi F, Yerle M, Barthenschlager H, Mattheeuws M, Van Zeveren A \& Peelman LJ (2006) Porcine PPARGC1A (peroxisome proliferative activated receptor gamma coactivator $1 \mathrm{~A}$ ): coding sequence, genomic organization, polymorphisms and mapping. Cytogenet Genome Res 112, 106-113.

37. Jung K, Park HJ, Kim YH \& Hong JP (2007) Expression of tumor necrosis factor-a and cyclooxygenase- 2 mRNA in porcine split-thickness wounds treated with epidermal growth factor by quantitative real-time PCR. Res Vet Sci 82, 344-348.

38. Rozen S \& Skaletsky HJ (2000) Primer3 on the WWW for general users and for biologist programmers. In Bioinformatics Methods and Protocols: Methods in Molecular Biology, pp. 365-386 [S Krawetz and S Misene, editors]. Totowa, NJ: Humana Press.

39. Altschul SF, Gish W, Miller W, Myers EW \& Lipman DJ (1990) Basic local alignment search tool. J Mol Biol 215, 403-410.

40. Zuker M (2003) Mfold web server for nucleic acid folding and hybridization prediction. Nucleic Acids Res 31, 3406-3415.

41. Vandesompele J, De Preter K, Pattyn F, Poppe B, Van Roy N, De Paepe A \& Speleman F (2002) Accurate normalization of real-time quantative RT-PCR data by geometric averaging of multiple internal control genes. Genome Biol 3, 0034.1-0034.11.

42. Gayet C, Leray V, Masayuki S, Siliarti B \& Nguyen P (2007) The effects of obesity-associated insulin resistance on mRNA expression of peroxisome proliferator-activated receptorgamma target genes, in dogs. Br J Nutr 98, 497-503.

43. Quesnel H \& Prunier A (1995) Endocrine basis of lactational anoestrus in the sow. Reprod Nutr Dev 35, 395-414.

44. Reseland JE, Haugen F, Hollung K, Solvoll K, Halvorsen B, Brude IR, Nenseter MS, Christiansen EN \& Drevon CA (2001) Reduction of leptin gene expression by dietary polyunsaturated fatty acids. J Lipid Res 42, 743-750.

45. Forman BM, Tontonoz P, Chen J, Brun RP, Spiegelman BM \& Evans RM (1995) 15-Deoxy-D-12,14-prostaglandin J2 is a ligand for the adipocyte determination factor PPARg. Cell 83, 803-812.

46. Mater MK, Pan D, Bergen WG \& Jump DB (1998) Arachidonic acid inhibits lipogenic gene expression in 3T3-L adipocytes through a prostanoid pathway. J Lipid Res 39, 1327-1334.

47. Rosen ED \& Spiegelman BM (2001) PPARgamma: a nuclear regulator of metabolism, differentiation, and cell growth. J Biol Chem 276, 37731-37734.

48. Feve B (2005) Adipogenesis: cellular and molecular aspects. Best Pract Res Clin Endocrinol Metab 19, 483-499.

49. Otto TC \& Lane MD (2005) Adipose development: from stem cell to adipocyte. Crit Rev Biochem Mol Biol 40, 229-242.

50. Gurnell M (2005) Peroxisome proliferator-activated receptor gamma and the regulation of adipocyte function: lessons from 
human genetic studies. Best Pract Res Clin Endocrinol Metab 19, 501-523.

51. Lin J, Handschin C \& Spiegelman BM (2005) Metabolic control through the PGC-1 family of transcription coactivators. Cell Metab 1, 361-370.

52. O'Rahilly S, Claire N, Johannes BP, Whitehead JP, Wentworth JM, Krishna V \& Chatterjee K (2001) Arachidonic acid stimulates glucose uptake in 3T3-L1 adipocytes by increasing GLUT1 and GLUT4 levels at the plasma membrane. $J$ Biol Chem 276, 9149-9157.

53. Pekala PH \& Long SD (1996) Regulation of GLUT4 gene expression by arachidonic acid. J Biol Chem 271, 1138-1144.

54. Kahn BB (1992) Facilitative glucose transporters: regulatory mechanisms and dysregulation in diabetes. J Clin Invest 89, $1367-1374$.

55. Neschen S, Morino K, Rossbacher JC, Pongratz RL, Cline GW, Sono S, Gillum M \& Shulman GI (2006) Fish oil regulates adiponectin secretion by a peroxisome proliferatoractivated receptor- $\gamma$-dependent mechanism in mice. Diabetes 55, 924-928.

56. John LT, Rule DC, Knabe DA, Mersmann HJ \& Smith AB (1987) Fatty acid-binding protein activity in tissues from pigs fed diets containing 0 and $20 \%$ high oleate oil. J Nutr 117, 2021-2026.

57. Luo J, Salwa WR, Vidal H, Oppert JM, Colas C, Guerre-Millo M, Chapuis AS, Chevalier A, Durand G \& Slama G (1998) Moderate intake of n-3 fatty acids for 2 months has no detrimental effect on glucose metabolism and could ameliorate the lipid profile of type 2 diabetic men. Diabetes Care 21, 717-724.

58. Murphy MC, Zampelas A, Puddicombe SM, Furlonger NP, Morgan LM \& Williams CM (1993) Pretranslational regulation of the expression of the lipoprotein lipase (EC 3.1, 1.3 4) gene by dietary fatty acids in the rat. Br J Nutr 70, 727-736.

59. Hube F, Lietz U, Igel M, et al. (1996) Difference in leptin mRNA levels between omental and subcutaneous abdominal adipose tissue from obese humans. Horm Metab Res 28, 690-693.

60. Masuzaki H, Ogawa Y, Isse N, et al. (1995) Human obese gene expression. Adipocyte-specific expression and regional differences in the adipose tissue. Diabetes 44, 855-858.

61. Masuzaki H, Ogawa Y, Shigemoto M, et al. (1995) Adipose tissue-specific expression of the obese (ob) gene in rats and its marked augmentation in genetically obese-hyperglycemic Wistar fatty rats. Proc Jpn Acad B 71, 148-152.

62. Cartwright IJ, Pockley AG, Galloway JH, et al. (1985) The effects of dietary $\omega-3$ polyunsaturated fatty acids on erythrocyte membrane phospholipids, erythrocyte deformability, and blood viscosity in healthy volunteers. Atherosclerosis 55, 267-281.

63. Lewis RA, Lee TH \& Austen KF (1986) Effects of omega-3 fatty acids on the generation of products of the 5-lipoxygenase pathway. In Health Effects of Polyunsaturated Fatty Acids in Seafoods, pp. 227-238 [AP Simopoulos, RR Kifer and RE Martin, editors]. Orlando, FL: Academic Press.

64. Weber PC \& Leaf A (1991) Cardiovascular effects of $\omega 3$ fatty acids: atherosclerotic risk factor modification by $\omega 3$ fatty acids. World Rev Nutr Diet 66, 218-232.

65. Pelton PD, Zhou L, Demarest KT \& Burris TP (1999) PPARgamma activation induces the expression of the adipocyte fatty acid binding protein gene in human monocytes. Biochem Biophys Res Commun 261, 456-458.

66. Yamauchi T, Kamon J, Waki H, et al. (2001) The fat-derived hormone adiponectin reverses insulin resistance associated with both lipoatrophy and obesity. Nat Med 7, 941-946.

67. Wu Z, Xie Y, Morrison RF, Bucher NL \& Farmer SR (1998) PPARgamma induces the insulin-dependent glucose transporter GLUT4 in the absence of C/EBP alpha during the conversion of 3T3 fibroblasts into adipocytes. J Clin Invest 101, 22-32.

68. Russell CD, Petersen RN, Rao SP, et al. (1998) Leptin expression in adipose tissue from obese humans: depot-specific regulation by insulin and dexamethasone. Am J Physiol Endocrinol Metab 275, 507-515.

69. Lonnqvist F, Nordfors L, Jansson M, Thorne A, Schalling M \& Arner P (1997) Leptin secretion from adipose tissue in women. Relationship to plasma levels and gene expression. J Clin Invest 99, 2398-2404.

70. Casabiell X, Pineiro V, Tome M, Peino R, Dieguez C \& Casanueva F (1997) Presence of leptin in colostrum and/or breast milk from lactating mothers: a potential role in the regulation of neonatal food intake. J Clin Endocrinol Metab 82, 4270-4273.

71. Estienne MJ, Harpera AF, Barb CR \& Azain MJ (2000) Concentrations of leptin in serum and milk collected from lactating sows differing in body condition. Domest Anim Endocrinol 19, 275-280.

72. Nelson BD (1990) Thyroid hormone regulation of mitochondrial function. Comments on the mechanism of signal transduction. Biochim Biophys Acta 1018, 275-277.

73. Leone TC, Lehman JJ, Finck BN, et al. (2005) PGC-1alpha deficiency causes multi-system energy metabolic derangements: muscle dysfunction, abnormal weight control and hepaticsteatosis. PLoS Biol 3, e101, 10.1371/journal.pbio.0030101. 